\title{
ВЛИЯНИЕ рН СРЕДЫ НА ДИНАМИКУ ПРОРАСТАНИЯ СПОР BACILLUS SUBTILIS
}

Яценко Е.С., Затонская Л.В., Петухов В.А., Лыков П.В.

\section{ФГБОУ ВПО Алтайский государственный университет, Барнаул, Россия mlprx@mail.ru}

DOI: 10.26902/ASFE-11_205

Для эффективного культивировании микроорганизмов показатель рН среды должен быть оптимальным для их роста. Устойчивость разных таксонов к изменениям кислотности различна, но для многих оптимальный показатель $\mathrm{pH}$ среды составляет 7,0 -7,6 [1]. Бактерии рода Bacillus аэробные, грамположительные, широко распространены в природе, устойчивы к воздействию химических и физических факторов среды. Особенностью рода Bacillus являются образование эндоспор - это особый тип покоящихся клеток, которые формируются эндогенно, т.е. внутри материнской клетки. Переход бактерий к спорообразованию наблюдается при истощении питательного субстрата, недостатке источников углерода, азота, фосфора, изменении $\mathrm{pH}$ [2]. При попадании в благоприятные условия или под влиянием физико-химических факторов происходит активация спор (1-2 минуты) с последующей инициацией и прорастанием (20-30 минут), и вырастанием в вегетативные клетки (60-90 минут) [3]. Активация осуществляется различными воздействиями - $\mathrm{pH}$, некоторыми веществами, повышением температуры, ультразвуком

Цель работы - определить оптимальную рН среды, при котором время прорастания споры минимально.

Для исследования были использованы бактерии Bacillus subtilis B-12079, Bacillus subtilis B- 2896, Bacillus subtilis B- 2895, Bacillus subtilis B- 4828, Bacillus subtilis B- 1323, Bacillus subtilis B- 5449. Из спор готовили суспензию: в колбу с питательной средой, состоящую из компонентов: пептон ферментативный, дрожжевой экстракт, натрий хлористый, сульфат аммония, вода дистиллированная вносили споры, титр 10-7. Значение рН среды варьировалось от 5 до 10. Культивировали в шейкер-инкубаторе «Innova 44» при 250 об/мин и температуре $37^{\circ}$. В качестве контрольной пробы рассматривались споры, культивируемые при рН среды 7,0-7,2. В ходе эксперимента каждые 10 минут контролировали состояния спор и бактериальных клеток на временных препаратах, а также производили подсчет процентного соотношения спор и вегетативных клеток. Для этого изготавливали мазки и окрашивали препараты по методу Пешкова. Бактериальные препараты анализировали на световом микроскопе Люмам ("Ломо", Россия). рН среды измеряли иономером рХ-150МИ.

В результате исследований было установлено: минимальное время прорастания спор при рН среды 8,0-8, 2. Первые вегетативные клетки появились через 50 мин, основное количество бактерий проросли через 80-90 минут. В контрольной пробе время прорастания в среднем 150 мин. Минимальное время прорастания показали штаммы Bacillus subtilis B-12079, Bacillus subtilis B- 4828, Bacillus subtilis B - 1323; среднее - штаммы Bacillus subtilis B- 2896, Bacillus subtilis B- 2895 время прорастания близкое к контрольной группе Bacillus subtilis B5449.

\section{Сиисок литературы}

1. Заядан В. К., Баймаханова Г. Б., Ораз Г., К. Болатхан, Зенина Е. В. Выделение новых штаммов цианобактерий и их консорциум с микроводорослями// Вестник Каз НУ Серия Экологическая. 2013 , Т. 37 № 1. 2. Федорова О. В., Юнусова 3. С., Назмиева А. И, Валеева Р. Т. Спорообразующие пробиотические микробные культуры и препараты на их основе// Вестник технологического университета. 2016. Т.19, №16, С. 166-170. 3. Озеров М.Ю., Попов В.Г., Каркищенко Н.Н., Попов Д.В., Пчелинце С.Ю, Каркищенко В.Н. Активация рецепторов прорастания спор В. anthracis //Биомедицина № 2, 2011, С. 18-23. 